\title{
Clinical Reasoning: Therapeutic considerations in myasthenic crisis due to COVID-19 infection
}

Phuong Hoang, MD, PhD, Brigitte Hurtubise, MD, and Srikanth Muppidi, MD

Neurology ${ }^{\circledR}$ 2020;95:840-843. doi:10.1212/WNL.0000000000010651

\section{Section 1}

In mid-March 2020, a 45-year-old woman with acetylcholine receptor antibody-positive myasthenia gravis $(\mathrm{MG})$ presented to a Northern California emergency department with 1 week of fever, sore throat, cough, as well as worsened diplopia, dysphagia, and slurred speech. She had been in contact with her father, who had similar upper airway symptoms followed by respiratory compromise and was in critical condition at another hospital.

The patient's outpatient MG regimen consisted of $10 \mathrm{mg}$ daily prednisone as well as plasma exchange (PLEX) every 2 weeks. Previous treatments including pyridostigmine, azathioprine, mycophenolate, tacrolimus, and IV immunoglobulin (IVIg) were either not effective or caused intolerable side effects. She had had multiple hospitalizations for myasthenic crises, some of which required endotracheal intubation. Previous MG flares were triggered by upper respiratory tract infections, similar to the current presentation. She refused thymectomy. She was being considered for eculizumab because of refractory MG, but had not yet had the necessary vaccinations.

The patient was admitted for worsening myasthenic symptoms and possible diagnosis of coronavirus disease 2019 (COVID-19).

\section{Question for consideration:}

1. What is the best next step in acute treatment for worsening MG symptoms for this patient?

\author{
Correspondence \\ Dr. Hoang \\ pthoang@stanford.edu
}

\section{MORE ONLINE}

COVID-19 Resources

For the latest articles, invited commentaries, and blogs from physicians around the world

NPub.org/COVID19

\section{GO TO SECTION 2}




\section{Section 2}

Patients with MG who develop respiratory infections are at risk for respiratory compromise. Treatment options for acute myasthenic worsening include (1) symptomatic (e.g., pyridostigmine); (2) immunosuppression (e.g., glucocorticoids); or (3) immunomodulatory treatments (i.e., IVIg or PLEX). ${ }^{1}$ Any underlying trigger, such as infection, should also be addressed. Care must be taken to avoid medications and treatments that would potentially worsen myasthenic symptoms.

IVIg and PLEX are the mainstay treatments for MG crises due to their rapid onset compared to other modalities. ${ }^{1}$ IVIg acts through unclear mechanisms to suppress inflammatory processes. PLEX works by removing plasma-soluble factors, including pathogenic autoantibodies and cytokines. Notably, IVIg and PLEX are considered equally effective in the treatment of moderate to severe generalized MG exacerbation, with similar duration of benefit. ${ }^{1}$ However, IVIg is easier to deliver, less costly, and better tolerated; therefore, it is often the first-line therapy for mild to moderate myasthenic exacerbations at many centers. On the other hand, for more severe crises, there is evidence that PLEX has superior efficacy compared to IVIg. ${ }^{1}$

PLEX is generally contraindicated in hemodynamically unstable patients due to significant and rapid fluid shifts. PLEX may theoretically worsen underlying infection as the process indiscriminately removes offending and protective antibodies. ${ }^{1-3}$
There are relatively few contraindications to IVIg, but rare adverse effects, including venous thrombosis, have been reported.

IVIg and PLEX, while relatively rapid acting, only provide benefit for a few weeks. Therefore, glucocorticoids are used concurrently in most patients to provide longer benefit, taking effect within weeks and peaking at $\sim 6$ months. ${ }^{1,2}$ Yet steroids may exacerbate infection and cause transient worsening of myasthenic symptoms. ${ }^{2}$ Despite these risks, steroids are often started or their dosing increased during MG exacerbations, even in the setting of infection, given the need for sustained immunosuppressive treatment. ${ }^{1}$

The patient initially required oxygen by nasal cannula. Chest $\mathrm{X}$-ray showed diffuse infiltrates. She was treated briefly with ceftriaxone for possible community-acquired pneumonia. Because of similar respiratory symptoms in her father and the ongoing pandemic, she was tested for severe acute respiratory syndrome coronavirus 2 (SARS-CoV-2) by nasopharyngeal PCR, which returned positive several days after it was sent. While awaiting this test result, she was presumed to have the virus and was kept in strict isolation.

\section{Questions for consideration:}

1. How does infection with SARS-CoV-2 influence options for the acute treatment of myasthenic crisis in this patient?

2. What additional considerations need to be taken in choosing PLEX for this patient?

\section{GO TO SECTION 3}




\section{Section 3}

At the time of presentation, there was significant concern regarding the use of glucocorticoids, as they have been shown to delay viral clearance of Middle East respiratory syndrome (MERS), ${ }^{4}$ provided no benefit and potential harm in patients with severe acute respiratory syndrome (SARS), ${ }^{4}$ and showed higher rates of intubation and death in the Wuhan cohort of patients with COVID-19. ${ }^{5}$ This led to an initial WHO recommendation to avoid initiation of systemic glucocorticoids in patients presenting with COVID-19. ${ }^{6}$ However, this recommendation also emphasized the need to weigh comorbid conditions for which steroids may be useful.

For our patient, while her respiratory status remained stable-no respiratory distress, normal negative inspiratory force (more than $40 \mathrm{~cm}$ of water) and forced vital capacity (66\%-92\%) measurements, no hypercarbia or hypoxemiaher myasthenic symptoms were debilitating (worsened gaze palsies, dysarthria, and severe dysphagia, requiring nasogastric tube for nutrition and medications). Therefore we decided to increase her steroids from 10 to $20 \mathrm{mg}$ of daily prednisone. In addition, given her past lack of response to IVIg, we decided to treat her with PLEX.

As discussed earlier, in most instances it may be more appropriate to use IVIg instead of PLEX in the setting of myasthenia and COVID-19 infection. One particular concern is that PLEX indiscriminately removes both harmful and protective antibodies. ${ }^{3}$ Of note, while the serologic response to COVID-19 has not yet been well-defined, early investigations show a typical immunologic response characterized by production of immunoglobulin M (IgM) followed by immunoglobulin G (IgG), mirroring decreased RNA values. ${ }^{7}$ The effect of reducing the titers of anti-SARS-CoV-2 IgM and IgG through PLEX is currently unknown.

Apart from protective antibody removal, PLEX may have additional downsides compared to IVIg in the treatment of COVID-19. These include longer duration of treatment: PLEX typically requires 5 sessions, each spaced out by at least 24 hours, necessitating increased hospital time and resources. Five PLEX sessions were needed to improve dysphagia in our patient, which required her to remain hospitalized for 10 days. PLEX itself is more labor intensive; while IVIg can be given by the patient's primary nurse using a standard IV pump, PLEX requires an additional specialized nurse as well as equipment that needs to be sterilized appropriately afterwards. Furthermore, PLEX often requires placement of a central catheter for vascular access, leading to increased exposure risk for staff.

\section{Discussion}

As of the writing of this article, there were no approved treatments, vaccines, or other preventative medications against COVID-19. However, several drugs have shown in vitro antiviral effects against SARS-CoV-2 and similar viruses (e.g., SARS and MERS). For example, hydroxychloroquine, an early drug of interest, acts by inhibiting entry of the virus into host cells. ${ }^{8}$ Early clinical studies from France and China garnered significant attention for the use of hydroxychloroquine and chloroquine against COVID-19, ${ }^{8}$ leading the Food and Drug Administration to grant emergency use authorization (EUA) in March 2020. However, in the face of larger studies showing lack of benefit and potential harm with hydroxychloroquine, the EUA was withdrawn less than 2 months later. ${ }^{9}$ Thus, while the temptation to reach for any potential treatment in the face of such a virulent pathogen is understandable, these early clinical studies and recommendations demonstrate that they must be approached with caution.

Subsequent focus has shifted to other agents, including antivirals such as remdesivir (also available through an extended access program), immunomodulators such as tocilizumab, and immunosuppressants such as dexamethasone. Notably, in June 2020, the RECOVERY trial's dexamethasone arm was halted due to efficacy in favor of dexamethasone treatment, showing one-third reduced mortality in intubated patients. ${ }^{10}$ Such promising results provide greater confidence in initiating or maintaining steroid therapy for patients with $\mathrm{MG}$ in crisis with COVID-19, as in our patient.

Ultimately, PLEX was believed to be the optimal treatment choice for the patient, in addition to increasing her prednisone dose as well as supportive care for COVID-19. Hydroxychloroquine was not given due to the risk of worsening myasthenic symptoms and, at the time, only poor quality evidence supporting its use. After 5 PLEX sessions, the patient's diplopia resolved and both her speech and swallow improved significantly. She was safely discharged home with appropriate outpatient care.

Two weeks following discharge (4 weeks after initial presentation), the patient's MG symptoms were still wellcontrolled. Repeat nasopharyngeal PCRs for SARS-CoV-2 remained positive, despite absence of any infectious symptoms. Whether this represents incomplete clearance of the virus, reinfection, overly high sensitivity of diagnostic testing, or laboratory error is unknown. However, this raises the concern that our patient's underlying immunosuppression, or increase thereof, affected her ability to clear the virus. Nevertheless, her stable MG symptoms proved her treatment course was overall successful. She eventually tested negative by nasal swab PCR about 2 months after presentation; at that time, she had positive SARS-CoV-2 IgG antibodies, yet was negative for IgM. Outpatient PLEX was deferred until she tested negative, out of concern for infecting other patients at the infusion center. PLEX has since resumed, and she remains on $20 \mathrm{mg}$ daily prednisone.

Our case illustrates the complexity of managing a critically ill neurologic patient during a pandemic with evolving evidence and treatment choices that may worsen underlying neurologic 
disease. Further studies will guide treatment as our understanding of this virus deepens.

\section{Study funding}

No targeted funding reported.

\section{Disclosure}

P. Hoang and B. Hurtubise report no disclosures. S. Muppidi serves on advisory boards for Alexion, Ra Pharmaceuticals, and Argenx. Go to Neurology.org/N for full disclosures.

\begin{tabular}{|c|c|c|}
\hline Name & Location & Contribution \\
\hline $\begin{array}{l}\text { Phuong } \\
\text { Hoang, } \\
\text { MD, PhD }\end{array}$ & $\begin{array}{l}\text { Department of Neurology } \\
\text { and Neurological Sciences, } \\
\text { Stanford University, Palo } \\
\text { Alto, CA }\end{array}$ & $\begin{array}{l}\text { Design and } \\
\text { conceptualization of study, } \\
\text { data collection and analysis, } \\
\text { drafting and revision of } \\
\text { manuscript }\end{array}$ \\
\hline $\begin{array}{l}\text { Brigitte } \\
\text { Hurtubise, } \\
\text { MD }\end{array}$ & $\begin{array}{l}\text { Department of Neurology } \\
\text { and Neurological Sciences, } \\
\text { Stanford University, Palo } \\
\text { Alto, CA }\end{array}$ & $\begin{array}{l}\text { Design and } \\
\text { conceptualization of study, } \\
\text { data collection and analysis, } \\
\text { drafting and revision of } \\
\text { manuscript }\end{array}$ \\
\hline
\end{tabular}

Appendix (continued)

\begin{tabular}{lll}
\hline Name & Location & Contribution \\
\hline Srikanth & Department of Neurology & $\begin{array}{l}\text { Design and conceptualization } \\
\text { Muppidi, }\end{array}$ \\
$\begin{array}{ll}\text { and Neurological Sciences, } \\
\text { of study, data collection and } \\
\text { MD }\end{array}$ & $\begin{array}{l}\text { Stanford University, Palo } \\
\text { Alto, CA }\end{array}$ & $\begin{array}{l}\text { of manuscript } \\
\end{array}$
\end{tabular}

\section{References}

1. Sanders DB, Wolfe GI, Benatar M, et al. International consensus guidance for man agement of myasthenia gravis: executive summary. Neurology 2016;87:419-425.

2. Sathasivam S. Steroids and immunosuppressant drugs in myasthenia gravis. Nat Clin Pract Neurol 2008;4:317-327.

3. Guptill JT, Juel VC, Massey JM, et al. Effect of therapeutic plasma exchange on immunoglobulins in myasthenia gravis. Autoimmunity 2016;49:472-479.

4. Arabi YM, Mandourah Y, Al-Hameed F, et al. Corticosteroid therapy for critically ill patients with Middle East respiratory syndrome. Am J Respir Crit Care Med 2017;197:757-767.

5. Guan W, Ni ZY, Hu Y, et al. Clinical characteristics of coronavirus disease 2019 in China. N Engl J Med 2020;382:1708-1720.

6. World Health Organization. Clinical management of severe acute respiratory infection (SARI) when COVID-19 disease is suspected: interim guidance. Geneva: World Health Organization; 2020

7. Zhao J, Yuan $\mathrm{Q}$, Wang H, et al. Antibody responses to SARS-CoV-2 in patients of novel coronavirus disease 2019. Clin Infect Dis Epub 2020 Mar 28.

8. Sanders JM, Monogue ML, Jodlowski TZ, Cutrell JB. Pharmacologic treatments for coronavirus disease 2019 (COVID-19): a review. JAMA Epub 2020 Apr 13.

9. Geleris J, Sun Y, Platt J, et al. Observational study of hydroxychloroquine in hospitalized patients with covid-19. N Engl J Med 2020;382:2411-2418.

10. Low-cost dexamethasone reduces death by up to one third in hospitalised patients with severe respiratory complications of COVID-19: RECOVERY trial. Available at: www.recoverytrial.net/news/low-cost-dexamethasone-reduces-death-by-up-to-onethird-in-hospitalised-patients-with-severe-respiratory-complications-of-covid-19. Accessed July 1, 2020.

\section{The AAN is at Your Side}

When you're in the office, the AAN is at your side. The AAN is your \#1 resource to support you and your care team. Whether it's resources to help you and your staff provide the best care for your patients, ensure proper reimbursement, or maximize practice performance, the AAN is at your side. Access these resources today at AAN.com/view/practiceresources.

\section{Announcing... \\ Child Neurology: A Case-Based Approach Cases from the Neurology ${ }^{\circ}$ Resident \& Fellow Section}

This collaboration between the American Academy of Neurology (AAN) and the Child Neurology Society (CNS) represents a collection of reprinted cases from the past 15 years from the Neurology Resident \& Fellow Section.

An invaluable resource for both adult and pediatric neurologists and trainees! FREE download: NPub.org/cnbook 


\section{Neurology}

\section{Clinical Reasoning: Therapeutic considerations in myasthenic crisis due to COVID-19 infection}

Phuong Hoang, Brigitte Hurtubise and Srikanth Muppidi

Neurology 2020;95;840-843 Published Online before print August 14, 2020

DOI 10.1212/WNL.0000000000010651

This information is current as of August 14, 2020

Updated Information \&

Services

References

Subspecialty Collections

Permissions \& Licensing

Reprints including high resolution figures, can be found at: http://n.neurology.org/content/95/18/840.full

This article cites 6 articles, 0 of which you can access for free at: http://n.neurology.org/content/95/18/840.full\#ref-list-1

This article, along with others on similar topics, appears in the following collection(s):

All Clinical Neurology

http://n.neurology.org/cgi/collection/all_clinical_neurology

All Immunology

http://n.neurology.org/cgi/collection/all_immunology

Myasthenia

http://n.neurology.org/cgi/collection/myasthenia

Viral infections

http://n.neurology.org/cgi/collection/viral_infections

Information about reproducing this article in parts (figures,tables) or in its entirety can be found online at:

http://www.neurology.org/about/about_the_journal\#permissions

Information about ordering reprints can be found online:

http://n.neurology.org/subscribers/advertise

Neurology ${ }^{\circledR}$ is the official journal of the American Academy of Neurology. Published continuously since 1951, it is now a weekly with 48 issues per year. Copyright @ 2020 American Academy of Neurology. All rights reserved. Print ISSN: 0028-3878. Online ISSN: 1526-632X.

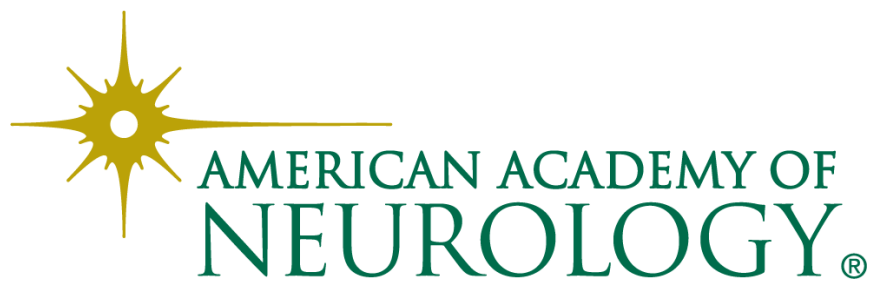

